\title{
ŠEIMŲ, AUGINANČIŲ VAIKUS SU AUTIZMO SPEKTRO SUTRIKIMU, GYVENIMO GEROVE்
}

\author{
Laimutė Samsonienė, Michail Bencion Malkin, Jonas Kairys, Algirdas Juozulynas \\ Vilniaus universiteto Medicinos fakultetas
}

Raktažodžiai: tėvai, vaikai su autizmo spektro sutrikimu, gyvenimo kokybè, specialieji poreikiai.

\begin{abstract}
Santrauka
Straipsnio tikslas - atskleisti tèvų, auginančių ikimokyklinio ar mokyklinio amžiaus vaiką su autizmo spektro sutrikimu, šeimos gyvenimo gerovès probleminius veiksnius.

Tyrime dalyvavo 100 tẻvų, auginančių ikimokyklinio ar mokyklinio amžiaus vaiką su autizmo spektro sutrikimu. Naudota nuoseklaus tyrimo strategija taikant anketinę apklausą su uždaro ir atviro tipo klausimais. Anketoje uždaro tipo klausimai skirti ištirti šeimos, auginančios vaiką su autizmo spektro sutrikimu, gyvenimo kokybę (angl. Family quality of life scale), o atviro tipo klausimai - šeimos specialiuju poreikių tenkinimo ypatumus. Tyrimo duomenų analizè atlikta naudojant Microsoft Office Excel ir SPSS programas. Rezultatai. Auginančios neiggalų ikimokyklinio amžiaus vaiką šeimos narių tarpusavio sąveikai svarbus neigalaus vaiko auklejimas $(\mathrm{r}=0,66)$, materiali $(r=0,53)$ ir emocinè $(r=0,51)$ šeimos gerové, o tèvams, auginantiems mokyklinio amžiaus neigalų vaiką, auklèjimas $(r=0,53)$ bei materiali gerovè $(r=0,53)$. Respondentai prastai ịvertino paramą, gaunamą iš valstybès, šeimos specialiesiems poreikiams tenkinti. Tik dalị reikalingų jų neigalaus vaiko raidai paslaugų galèjo ịpirkti patys, o kitos dalies paslaugu ịpirkti negalèjo dèl šeimos prastos finansinès padèties.

Išvados. Visuomenès pastangos tinkamai pasirūpinti šeimos, auginančios neigalų vaiką, gyvenimo gerove, priklauso nuo gebejjimo sistemiškai atskleisti santykiu šeimoje ir socialiniu santykiu psichosocialinio funkcionavimo ypatumus bei specialistu teikiamos pagalbos šeimai iš formalių ir/ar neformalių struktūrų poreikị ir lūkesčius.
\end{abstract}

\section{Ivadas}

Per pastaraji dešimtmetị, mokslininkų atlikti tyrimai atskleide, kad šeimoms, auginančioms vaiką su autizmo spektro sutrikimu, atsiranda problemu su kokybišku nemokamų paslaugų gavimu iš valstybès. Šeimos, kurios patiria finansinių problemų, susijusių su neịgalaus vaiko būkle, yra priverstos ieškoti mažiau efektingų, tačiau finansiškai prieinamų neigalaus vaiko ugdymosi, reabilitacijos ir rekreacijos paslaugų.

Šeimos gyvenimo gerovè ir tinkamas funkcionavimas priklauso nuo jos įsipareigojimų valstybei, palaikant tokias funkcijas kaip: materialiniai resursai, saugumas, vaiko auginimas ir rūpinimas bei komunikabilumas, socializacija [1] Tẻvai, auginantys vaiką su autizmo spektro sutrikimu, turi daugiau problemų ir yra didesneje rizikoje atsirasti fizinèms ir psichologinèms problemoms, nei tèvai, auginantys vaiką su kitu sutrikimu [2]. Vaiko su negalia auginimas apriboja tẻvų dalyvavimą visuomeniniame gyvenime. Tẻvų teigimu, artimuju parama, pagalba, auginant vaiką su negalia, yra svarbus jų saugumo, galimybès save realizuoti, socialinio aktyvumo veiksnys [3].Vaikams su autizmo spektro sutrikimu dažniausiai nustatomas elgesio sutrikimo simptomu kompleksas, kuris reikalauja plataus spektro intervencinių iš ịvairių sričių sveikatos priežiūros specialistų programų [4]. Dèl padidejusio autizmo spektro paplitimo, atsiranda didelis paramos bei sveikatos priežiūros paslaugų poreikis, reikalingas vaikų elgesio ir raidos vystymuisi viso jų gyvenimo periodu [5]. Tačiau šeimoms, auginančioms vaiką su autizmo spektro sutrikimu, atsiranda ịvairiu problemų siekiant pagalbos ir sveikatos priežiūros paslaugų [6]. Pagrindinis būdas gerinti šeimų gyvenimo gerovę yra ịvertinti jų prioritetus ịvairaus spektro pagalbai ir paslaugoms bei taikyti šeimai reikalingas ir kokybiškas paslaugas, atitinkančias jos poreikius ir lūkesčius.

Tyrimo tikslas - atskleisti tèvų, auginančių ikimokyklinio ar mokyklinio amžiaus vaiką su autizmo spektro sutrikimu, šeimos gyvenimo gerovės probleminius veiksnius.

\section{Tyrimo medžiaga ir metodai}

Tyrimas vykdytas 2015 metais gegužès ir spalio mènesiais. Vienmomentinis tyrimas atliktas: Všt ,Vaiko raidos 
centre“, VšI „ABOS centre“, Vilniaus specialiame lopšelyje-darželyje „Čiauškutis”, „Čiauškučio“ dienos centre, Vilniaus „Atgajos“ specialioje mokykloje, Vilniaus neigaliujų dienos centre, Lietuvos autizmo asociacijoje „Lietaus vaikai“, Všį “ISADD Lietuva”, „Pojūčių klinika“, „Vaikų slènis“. İstaigų vadovai leido tyrimą atlikti. Atsitiktinès tikslinès atrankos būdu suformuota 100 respondentų imtis - anketų išdalinta 130, sugrižzo 104 anketos. Pagal atrankos kriterijus tèvai, auginantys ikimokyklinio ir/ar mokyklinio amžiaus vaiką su autizmo spektro sutrikimu (ASS), tyrimui atrinkta 100 anketų. Respondentai suskirstyti ị dvi grupes pagal auginamų vaikų amžių: ikimokyklinio amžiaus vaikas su $\operatorname{ASS}(n=50)$, antroji grupè- mokyklinio amžiaus vaikas su ASS(n=50). Imties charakteristika: 91 moteris ir 9 vyrai; amžius - 36,7 $\pm 5,9$ metai; profesinio darbo patirtis - 12,7 $\pm 6,5$ metai; turimų vaikų skaičius $-2,0 \pm 0,9$; sutrikimą turinčio vaiko amžius $-6,9 \pm 2,8$ metai; 77 proc. gyvena didmiestyje, 23 proc. gyvena rajono centruose, kaimuose, miesteliuose; išsilavinimas - 66 proc. turi aukštaji, 12 proc. aukštesni, 11 proc. profesini, 11 proc.vidurini; 87 proc. gyvena pilnoje šeimoje, 13 proc. gyvena nepilnoje šeimoje. Siekiant ištirti šeimos, auginančios ikimokyklinio ir/ar mokyklinio amžiaus vaiką su ASS gyvenimo gerovès veiksnius - gyvenimo kokybę ir specialių poreikių tenkinimo ypatumus, buvo taikytas nuoseklaus tyrimo dizainas. Tẻvų gyvenimo kokybė vertinta taikant standartizuotą "Šeimos gyvenimo kokybės klausimyną" (angl. Family qality of life scale). Šis klausimynas yra orientuotas į šeimos narių tarpusavio santykius, asmens sveikatą ir skirtas šeimoms, auginančioms vaiką ASS. Tačiau šis tyrimo instrumentas nèra klinikinè priemonè, kuri skirta nustatyti ar paneigti teikiamų šeimai specialiujų paslaugų tinkamumą ir/ar kokybę [7-8]. Atskleisti respondentų nuostatas ị gaunamas paslaugas ir/ar pagalbą šeimos specialiujų poreikių tenkinimui ir išskirti jų problematiką, ị apklausą buvo ịtraukti atviro tipo klausimai. I atvirus klausimus atsakè visi tyrime dalyvavę tèvai. Analizuojant duomenis taikyta skelbiamoji (manifestinè) kokybinio turinio analizè, pritaikant indukcinį tyrimo metodą (1 pav.). Tyrimui naudotas instrumentas - lentele, kuri sudaryta iš kategorijų ir subkategorijų bei jas patvirtinančių tėvų teiginių apie gaunamas specialias šeimai paslaugas, jų poreikị ir lūkesčius [9].

Tyrimo duomenų analizė atlikta naudojant Microsoft Office Excel ir SPSS programas. Naudota aprašomoji statistika, skaičiuota: Kronbach'o (Cronbach) alfa koeficientas, Faktorinè analizè, Spirmen'o (Spearmen) koreliacija, Smirnovo-Kolmogorovo (Smirnov-Kolmagorov)testas.

\section{Gauti rezultatai ir jų aptarimas}

Tyrimas padejo atskleisti sąsajas tarp šeimos gyvenimo kokybès sričių ir neịgalaus vaiko amžiaus tarpsnio (1 len-

1 lentelè. Šeimos gyvenimo kokybės sričių tarpusavio sąsajos tarp respondentų, turinčių ikimokyklinio ar mokyklinio amžiaus vaiką su ASS (Spearmen) koreliacija)

$r$ - koreliacijos koficientas (skaičiai su ,, + “ ženklu rodo tiesiogini funkcinị ryšĭ, o su ženklu ,,- “ rodo atvirkštini funkcini ryši); p - patikimumas; $N$ - respondentu skaičius

\begin{tabular}{|c|c|c|c|c|c|c|c|c|c|c|c|}
\hline \multirow{2}{*}{\multicolumn{2}{|c|}{$\begin{array}{l}\text { Ikimokyklinio } \\
\text { amžiaus }\end{array}$}} & \multicolumn{2}{|c|}{$\begin{array}{c}\text { Šeimos tarpusavio } \\
\text { sąveika }\end{array}$} & \multicolumn{2}{|c|}{ Auklèjimas } & \multicolumn{2}{|c|}{ Emocinė gerovė } & \multicolumn{2}{|c|}{ Materiali gerovè } & \multicolumn{2}{|c|}{$\begin{array}{c}\text { Parama šeimos } \\
\text { neigaliajam }\end{array}$} \\
\hline & & \multirow{2}{*}{$\begin{array}{c}\begin{array}{c}\text { Mokykli- } \\
\text { nio am- } \\
\text { žiaus }\end{array} \\
1,000 \\
\end{array}$} & \multirow{2}{*}{$\begin{array}{c}\begin{array}{c}\text { Ikimokykli- } \\
\text { nio amžiaus }\end{array} \\
1,000 \\
\end{array}$} & \multirow{2}{*}{$\begin{array}{c}\begin{array}{c}\text { Mokyklinio } \\
\text { amžiaus }\end{array} \\
0,668 \\
\end{array}$} & \multirow{2}{*}{$\begin{array}{c}\begin{array}{c}\text { Ikimo- } \\
\text { kyklinio } \\
\text { amžiaus }\end{array} \\
0,535 \\
\end{array}$} & \multirow{2}{*}{$\begin{array}{c}\begin{array}{c}\text { Mokykli- } \\
\text { nio am- } \\
\text { žiaus }\end{array} \\
0,512 \\
\end{array}$} & \multirow{2}{*}{$\begin{array}{c}\begin{array}{c}\text { Ikimokykli- } \\
\text { nio amžiaus }\end{array} \\
0,232 \\
\end{array}$} & \multirow{2}{*}{$\begin{array}{c}\begin{array}{c}\text { Mokykli- } \\
\text { nio am- } \\
\text { žiaus }\end{array} \\
0,535 \\
\end{array}$} & \multirow{2}{*}{$\begin{array}{c}\begin{array}{c}\text { Ikimo- } \\
\text { kyklinio } \\
\text { amžiaus }\end{array} \\
0,374 \\
\end{array}$} & \multirow{2}{*}{$\begin{array}{c}\begin{array}{c}\text { Mokykli- } \\
\text { nio am- } \\
\text { žiaus }\end{array} \\
0,218 \\
\end{array}$} & \multirow{2}{*}{$\begin{array}{c}\begin{array}{c}\text { Ikimo- } \\
\text { kyklinio } \\
\text { amžiaus }\end{array} \\
-0,032 \\
\end{array}$} \\
\hline Šeimos & $r$ & & & & & & & & & & \\
\hline tarpusavio & $p$ & . & . & 0,000 & 0,000 & 0,000 & 0,105 & 0,000 & 0,007 & 0,129 & 0,824 \\
\hline sąveika & $N$ & 50 & 50 & 50 & 50 & 50 & 50 & 50 & 50 & 50 & 50 \\
\hline \multirow{3}{*}{ Auklëjimas } & $r$ & 0,668 & 0,535 & 1,000 & 1,000 & 0,525 & 0,407 & 0,721 & 0,533 & 0,527 & 0,321 \\
\hline & $p$ & 0,000 & 0,000 & . & . & 0,000 & 0,003 & 0,000 & 0,000 & 0,000 & 0,023 \\
\hline & $N$ & 50 & 50 & 50 & 50 & 50 & 50 & 50 & 50 & 50 & 50 \\
\hline \multirow{3}{*}{$\begin{array}{l}\text { Emocinè } \\
\text { gerové }\end{array}$} & $r$ & 0,512 & 0,232 & 0,525 & 0,407 & 1,000 & 1,000 & 0,491 & 0,417 & 0,481 & 0,617 \\
\hline & $p$ & 0,000 & 0,105 & 0,000 & 0,003 & . & . & 0,000 & 0,003 & 0,000 & 0,000 \\
\hline & $N$ & 50 & 50 & 50 & 50 & 50 & 50 & 50 & 50 & 50 & 50 \\
\hline \multirow{3}{*}{$\begin{array}{l}\text { Materiali } \\
\text { gerovė }\end{array}$} & $r$ & 0,535 & 0,374 & 0,721 & 0,533 & 0,491 & 0,417 & 1,000 & 1,000 & 0,794 & 0,644 \\
\hline & $p$ & 0,000 & 0,007 & 0,000 & 0,000 & 0,000 & 0,003 & . & . & 0,000 & 0,000 \\
\hline & $N$ & 50 & 50 & 50 & 50 & 50 & 50 & 50 & 50 & 50 & 50 \\
\hline \multirow{3}{*}{$\begin{array}{l}\text { Parama } \\
\text { šeimos neį- } \\
\text { galiajam }\end{array}$} & $r$ & 0,218 & $-0,032$ & 0,527 & 0,321 & 0,481 & 0,617 & 0,794 & 0,644 & 1,000 & 1,000 \\
\hline & $p$ & 0,129 & 0,824 & 0,000 & 0,023 & 0,000 & 0,000 & 0,000 & 0,000 & . & . \\
\hline & $N$ & 50 & 50 & 50 & 50 & 50 & 50 & 50 & 50 & 50 & 50 \\
\hline
\end{tabular}




\begin{tabular}{|c|c|c|c|}
\hline $\begin{array}{l}\text { Duomenų rinkimas ir } \\
\text { atsakymų j atvirus } \\
\text { klausimus skaitymas }\end{array}$ & $\begin{array}{l}\text { Iš surinktos } \\
\text { informacijos } \\
\text { (duomenų) išskiriami } \\
\text { esminiai aspektai } \\
\text { (teiginiai), kuriuos } \\
\text { atspindi frazės, } \\
\text { sakiniai, žodžiai susiję } \\
\text { su specialiujų poreikių } \\
\text { tenkinimo sąlygomis. }\end{array}$ & $\begin{array}{l}\text { Esminiams aspektams } \\
\text { (teiginiams) } \\
\text { suteikiami } \\
\text { pavadinimai } \\
\text { (subkategorijos). Prie } \\
\text { kiekvienos } \\
\text { subkategorijos } \\
\text { pateikiami pavyzdžiai, } \\
\text { subkategorijų } \\
\text { pagrìstumo i̇rodymai } \\
\text { (tai yra teiginiai) }\end{array}$ & $\begin{array}{l}\text { Subkategorijų grupé } \\
\text { jungiama i kategoriją } \\
\text { (as). } \\
\text { Kategorijos } \\
\text { plètojamos ir siejamos } \\
\text { viena su kita, } \\
\text { apjungiant jas j̇ temą, } \\
\text { jungiančią tyrimo } \\
\text { duomenų visumą. }\end{array}$ \\
\hline
\end{tabular}

1 pav. Indukcinė kokybinių duomenų analizė

2 lentelè. Faktorių pasuktoji matrica

\begin{tabular}{|l|l|l|}
\hline \multirow{2}{*}{ Šeimos gyvenimo kokybės sritis } & \multicolumn{2}{|c|}{ Faktorius } \\
\cline { 2 - 3 } & $\begin{array}{c}\text { Socialiniai } \\
\text { santykiai }\end{array}$ & $\begin{array}{c}\text { Santykiai } \\
\text { šeimoje }\end{array}$ \\
\hline Šeimos tarpusavio sąveika & 0,086 & 0,946 \\
\hline Auklèjimas & 0,394 & 0,818 \\
\hline Emocinė gerovė & 0,714 & 0,308 \\
\hline Materiali gerovė & 0,814 & 0,361 \\
\hline Parama šeimos neigaliajam & 0,951 & 0,018 \\
\hline
\end{tabular}

telè). Tèvų, auginančių ikimokyklinio amžiaus vaiką (I grupè), geresnè emocinè gerovè susijusi ir su stipresne šeimos tarpusavio sąveika $(\mathrm{r}=0,51$; $\mathrm{p}=0,00$ ), tačiau tarp tèvų, turinčių mokyklinio amžiaus vaiką ( II grupè), ši sąveika nebèra statistiškai reikšminga ( $p>0,05)$, t. y. geresnè emociné gerovè nebėra susijusi su stipresne šeimos tarpusavio sąveika. Taip pat nustatyta, kad respondentų šeimos tarpusavio sąveika su parama šeimos neigaliajam nebuvo reikšminga ( $p>0,05)$, t.y. didesnè šeimos tarpusavio sąveika nèra susijusi su didesne parama šeimos neigaliajam. Respondentų stipresnè šeimos tarpusavio sąveika susijusi su dèmesingu ir atsakingu auklejjimu bei geresne fizine materialia gerove $(p<0,05)$, o geresnè emocinè gerovè susijusi su dèmesingu ir atsakingu auklèjimu šeimoje $(p<0,05)$, tačiau pirmos grupès tèvų koreliacijos ryšys yra vidutinio stiprumo $(\mathrm{r}=0,525 ; \mathrm{p}=0,00)$, o mokyklinio amžiaus tèvu silpnas $(\mathrm{r}=0,4 ; \mathrm{p}=0,003)$. Respondentų didesnè parama šeimos neigaliajam susijusi su dèmesingu ir atsakingu auklèjimu bei geresne fizine materialia gerove $(p<0,05)$, taip pat didesnè parama šeimos neigaliajam daro poveiki šeimos emocinei gerovei. Parama neigaliam vaikui šeimoje turi stiprius ryšius su šeimos materialia padètimi (I gr. $r=0,79$, IIgr. $r=0,64 ; p<0.05$ ), tačiau su
3 lentelè. Valstybès pagalba, paslaugos tèvams, auginantiems ikimokyklinio amžiaus vaiką su ASS

\begin{tabular}{|c|c|c|c|}
\hline Kategorija & Subkategorija & Teiginiai & $\begin{array}{c}\text { Teiginių } \\
\text { dažnis }\end{array}$ \\
\hline \multirow[t]{3}{*}{$\begin{array}{l}\text { Finansiné } \\
\text { parama }\end{array}$} & $\begin{array}{l}\text { Neigalumo } \\
\text { išmokos }\end{array}$ & $\begin{array}{l}\text { “...soc. išmoką", “...neigalumo pa- } \\
\text { šalpą...”, “...neigalumo ir priežiūros } \\
\text { išmokos", "Vaikas gauna šalpą...”, } \\
\text { “...parama, pavežejimas", }\end{array}$ & \multirow{3}{*}{17} \\
\hline & $\begin{array}{l}\text { Sumažinti } \\
\text { mokesčiai }\end{array}$ & $\begin{array}{l}\text { “...sumažintas mokestis už darželị”, } \\
\text { "...lankyti spec. darželị mokant už jo } \\
\text { lankymą sumažintą kainą", }\end{array}$ & \\
\hline & $\begin{array}{l}\text { Kitos soc. } \\
\text { išmokos }\end{array}$ & 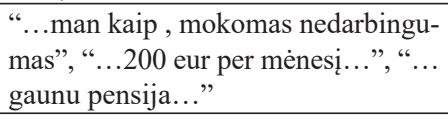 & \\
\hline \multirow{3}{*}{$\begin{array}{l}\text { Parama } \\
\text { spec. ugdy- } \\
\text { mui }\end{array}$} & Spec. darželiai & $\begin{array}{l}\text { "Darželị....", "spec. darželị”, “...lo- } \\
\text { gopedinị darželį..." }\end{array}$ & \multirow{3}{*}{24} \\
\hline & $\begin{array}{l}\text { Spec. moky- } \\
\text { klèlès }\end{array}$ & $\begin{array}{l}\text { "ugdymo įstaigą...”, “. ...autistų moky- } \\
\text { klèlè VRC",“...strukturuotą mokymą } \\
\text { VRC mokyklėlèj”, }\end{array}$ & \\
\hline & $\begin{array}{l}\text { Spec. ugdymo } \\
\text { centrai }\end{array}$ & $\begin{array}{l}\text { "...dienos centras", “...soc. centras", } \\
\text { "... užsièmimai spec. centre”, "dienos } \\
\text { centras "Čiauškutis"...", }\end{array}$ & \\
\hline \multirow[t]{3}{*}{$\begin{array}{l}\text { Parama } \\
\text { reabilita- } \\
\text { cijai }\end{array}$} & $\begin{array}{l}\text { Specialistų } \\
\text { konsultacijos }\end{array}$ & 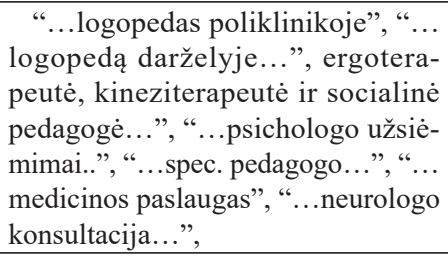 & 19 \\
\hline & $\begin{array}{l}\text { Reabilitacija } \\
\text { ligoninėse/ } \\
\text { sanatorijose }\end{array}$ & 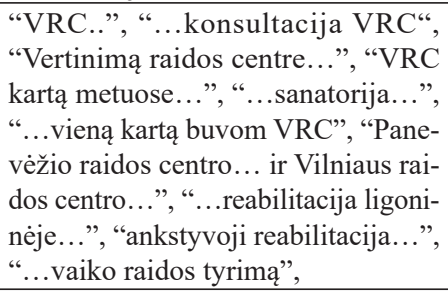 & 18 \\
\hline & $\begin{array}{l}\text { Dienos paslau- } \\
\text { gos }\end{array}$ & "dienos socialinè globa..." & 1 \\
\hline
\end{tabular}

šeimos narių tarpusavio sąveika - statistiškai nereikšminga $(\mathrm{p}>0,05)$, t.y. didesnè šeimos tarpusavio sąveika nèra susijusi su didesne parama šeimos neigaliajam. 
4 lentelè. Valstybės pagalba, paslaugos tėvams, auginantiems mokyklinio amžiaus vaiką su ASS

\begin{tabular}{|c|c|c|c|}
\hline Kategorija & Subkategorija & Teiginiai & $\begin{array}{c}\text { Teiginiụ } \\
\text { dažnis }\end{array}$ \\
\hline \multirow[t]{2}{*}{ Finansinė parama } & Neigalumo išmokos & $\begin{array}{l}\text { "Pašalpa...", "Šalpos pensija”, “...neiga- } \\
\text { lumo pašalpas...", " ...negalès pinigus", } \\
\text { "Neigalumo išmoka...", }\end{array}$ & \multirow[b]{2}{*}{28} \\
\hline & Kitos soc. išmokos & $\begin{array}{l}\text { "Nemokamą maitinimą ir nemokamą vežio- } \\
\text { jimą", "transportas, maitinimo parama...", } \\
\text { "...kompensuojamus vaistus", “....pietūs } \\
\text { mokykloje" }\end{array}$ & \\
\hline \multirow[t]{2}{*}{$\begin{array}{l}\text { Parama spec. ug- } \\
\text { dymui }\end{array}$} & Spec. Mokyklos & 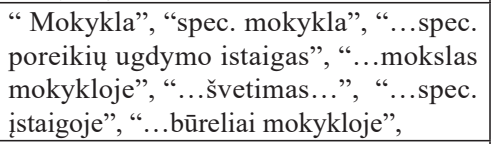 & \multirow[t]{2}{*}{20} \\
\hline & $\begin{array}{l}\text { Spec. ugdymo } \\
\text { centrai }\end{array}$ & $\begin{array}{l}\text { “...globos centro lankymas", “....dienos } \\
\text { centrą", “....veikla neigaliujų bendrijose”, }\end{array}$ & \\
\hline \multirow[t]{2}{*}{$\begin{array}{l}\text { Parama reabilita- } \\
\text { cijai }\end{array}$} & $\begin{array}{l}\text { Specialistų konsul- } \\
\text { tacijos }\end{array}$ & $\begin{array}{l}\text { "Tik logopedo pagalba", "logopedo pa- } \\
\text { galbą... ir ...mokytojo padejejo pagalbą } \\
\text {...", "Mokytojo padejèja mokykloje...", } \\
\text { "mokykloje logopedo, spec. pedagogo", } \\
\text { "...psichologo", “...ISAD Lietuva" }\end{array}$ & 10 \\
\hline & $\begin{array}{l}\text { Reabilitacija ligoni- } \\
\text { nèse/ } \\
\text { sanatorijose }\end{array}$ & $\begin{array}{l}\text { "...tyrimus VRC...”, “.... reabilitacija sana- } \\
\text { torijoje... reabilitacija Santariškèse...”, “.... } \\
\text { Raidos centrą", “...kartą per metus būname } \\
\text { Raidos centre”, “....medicinos paslaugas”" }\end{array}$ & 6 \\
\hline
\end{tabular}

5 lentelè. Pagalba, paslaugos, kurias perka tėvai, auginantys ikimokyklinio amžiaus vaiką su ASS

\begin{tabular}{|c|c|c|c|}
\hline Kategorija & Subkategorija & Teiginiai & $\begin{array}{c}\text { Teiginiụ } \\
\text { dažnis }\end{array}$ \\
\hline \multirow[t]{2}{*}{$\begin{array}{l}\text { Parama spec. } \\
\text { ugdymui }\end{array}$} & $\begin{array}{l}\text { Papildomas ug- } \\
\text { dymas }\end{array}$ & $\begin{array}{l}\text { "Papildomi ugdymo užsièmimai”, “...papildomi užsièmi- } \\
\text { mai...", "ikimokyklinė ugdymo ịstaiga" } \\
\text { “...privatus darželis...papildomas ugdymas" }\end{array}$ & 4 \\
\hline & $\begin{array}{l}\text { Spec. ugdymo } \\
\text { centrai }\end{array}$ & "Neįgaliųų dienos centras", & 1 \\
\hline \multirow[t]{2}{*}{$\begin{array}{l}\text { Parama } \\
\text { reabilitacijai }\end{array}$} & $\begin{array}{l}\text { Specialistu kon- } \\
\text { sultacijos }\end{array}$ & $\begin{array}{l}\text { "Psichologą...", “...logopedas", "Medicinos specialistų, } \\
\text { logopedo, ergoterapeuto, kineziterapeuto, osteopato...", } \\
\text { "Lankome privačiai...", “....spec. pedagogas...", "Specia- } \\
\text { listu pagalbos ịvairios", }\end{array}$ & 29 \\
\hline & $\begin{array}{l}\text { Reabilitacija } \\
\text { ligoninèse/ } \\
\text { sanatorijose/ }\end{array}$ & 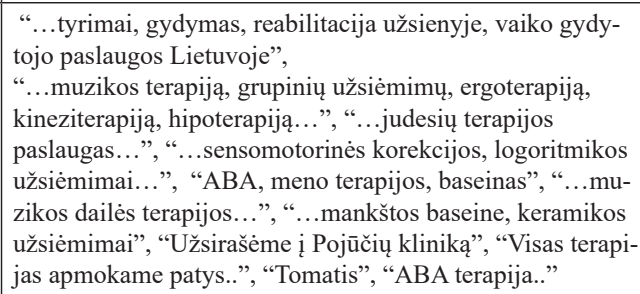 & 23 \\
\hline \multirow[t]{3}{*}{$\begin{array}{l}\text { Kitos } \\
\text { paslaugos }\end{array}$} & Med.paslaugos & $\begin{array}{l}\text { "Dantisto paslaugos", "Odontologų paslaugas...”, “... } \\
\text { kartais privačios medicinos paslaugos...", “....kai kurias } \\
\text { medicinines", }\end{array}$ & 4 \\
\hline & $\begin{array}{l}\text { Priemonės, žais- } \\
\text { lai ir kiti reika- } \\
\text { lingi daiktai }\end{array}$ & $\begin{array}{l}\text { “...ivairias priemones”, "Reikiamų lavinimo priemonių } \\
\text { pirkimas...”, “....neigalaus vaiko higieniniai poreikiai - } \\
\text { sauskelnès...", "Ivairias priemones ugdymui, lavinančius } \\
\text { žaislus, programèles knygutes ir pan.” }\end{array}$ & 4 \\
\hline & Vaiko priežiūra & $\begin{array}{l}\text { “...kartais auklès paslaugos...”,“...lydintis asmuo darže- } \\
\text { lyje..." }\end{array}$ & 2 \\
\hline
\end{tabular}

Tyrimo duomenimis, išskirti latentiniai gyvenimo kokybès faktoriai, kurie turi poveikị šeimos gyvenimo sričių komponentams (2 lentelè). Faktorinès analizès metodu nustatyti du faktoriai, kuriems suteikti sąlyginiai pavadinimai: socialiniai santykiai ir santykiai šeimoje. Socialinių santykių faktorius yra siejamas su: šeimos materialia gerove $(0,8)$, emocine gerove $(0,7)$ bei parama neigaliajam $(0,95)$. Išryškejjo įdomus faktas, $\mathrm{kad}$ šeimose, kuriose yra stipri parama neigaliam vaikui, taip pat yra ir stipri fizinè materialinè ir emocinè gerové, tačiau šeimos tarpusavio sąveika $(0,08)$ ir auklejjimas $(0,3)$ poveikio socialiniams santykiams neturi. Santykių šeimoje faktorius yra siejamas su: šeimos tarpusavio sąveika $(0,9)$ ir auklèjimu (0,8). Šeimose, kuriose yra stipri šeimos narių tarpusavio sąveika, svarbus ir auklejjimas, tačiau emocinè ir materiali gerovè bei parama šeimos neigaliajam santykiams šeimoje poveikio neturi.

Kitas svarbus šeimos gerovès veiksnys yra ịvairių sričių specialistų teikiama pagalba. Visos paslaugos terapijos ir intervencijos reikalauja glaudaus tèvų bendradarbiavimo su specialistais. Tačiau mokslininkų duomenimis, dauguma tèvų įvardija teikiamos pagalbos problemas: trūksta specialistų pagalbos, paslaugos būna arba nepasiekiamos tèvams, arba tiesiog per brangios [10]. Be to, tevai gauna nepakankamai informacijos iš specialistu jiems rūpimais klausimais: apie neigalaus vaiko auginimą ir auklëjimą, apie teikiamų paslaugų ịvairovę, apie pagalbą, padedančią palaikyti sẻkmingą šeimos funkcionavimą [11]. Specialistai turi nemaža itakos šeimos gyvenimo gerovei. Didžiają laiko dali jiems tenka praleisti su šeima, jos nariais, tenkinant ne tik neiggalaus vaiko, bet ir visos šeimos poreikius [10]. Gerinant šeimų, auginančių vaikus su ASS, gyvenimo 
gerovę, svarbu žinoti ir įvertinti individualius šeimos specialiuosius poreikius bei juos patenkinti laiku ir kokybiškai [5].

Tyrimas padejo atskleisti šeimų specialiųų poreikių tenkinimo problemas užduodant 3 atviro tipo klausimus: apie gaunamą pagalbą iš valstybès, apie pačių perkamas paslaugas ir apie paslaugas, kurių jiems trūksta. Analizuojant pirmojo klausimo duomenis buvo išskirti prasminiai vienetai (subkategorijos), kurie pagal savo turini suformavo tris kategorijas: finansine parama, parama specialiajam ugdymui ir parama reabilitacijai $(3,4$ lentelès). Respondentai nurodé, kad iš valstybès gauna: neịgalumo išmokas, sumažintus mokesčius bei kitas socialines išmokas( finansinè parama); pritaikytus neigaliam vaikui darželius, specialias mokyklèles, specialiojo ugdymo centrus (parama specialiajam ugdymui); ivairiu sričių specialistų konsultacijas, reabilitaciją ligoninėse ar sanatorijose bei dienos paslaugas (parama reabilitacijai). Tačiau ịvertinus teiginių dažnị buvo pastebèta, kad valstybès teikiama parama šeimai, auginančiai vaiką su ASS, priklauso nuo vaiko amžiaus tarpsnio: pirmoje grupejje nustatyta, kad didžiausias dėmesys valstybès skiriamas reabilitacijos poreikių tenkinimui, o mažiausias - finansinei paramai; antroje grupèje didžiausias dèmesys finansinei paramai ir specialiajam ugdymui, o mažiausias reabilitacijai.

Vienas svarbiausių šeimos, auginančios vaiką su negalia, iggalinimo veiksnių yra ịvairių sričių specialistų teikiama pagalba, kuri visapusiškai visą gyvenimą veikia šeimos gyvenimo kokybę. Tyrime nustatytas sumažèjęs valstybės dėmesys mokyklinio amžiaus vaikų su ASS reabilitacijai, tikrai nepagerins šeimos gyvenimo kokybės.

Šeimos gyvenimo kokybe ir tinkamas funkcionavimas priklauso nuo šeimos įsipareigojimų valstybei palaikant jos funkcijas tokias kaip: materialiniai resursai, saugumas, vaiko auginimas ir rūpinimas bei komunikabilumas ir socializacija, bet ne nuo vaiko amžiaus tarpsnio $[12,10,1]$.

Analizuojant antrojo klausimo duomenis apie tèvų perkamas paslaugas, išskirti prasminiai teksto vienetai (subkategorijos) buvo sujungti ị tris kategorijas: parama specialiajam ugdymuisi, parama reabilitacijai ir kitos paslaugos (5,6 lentelès). Tyrimo duomenimis, visi tyrime dalyvavę tèvai daugiausia perka reabilitacijos paslaugas (nors jas gauna iš valstybès), ieško ir perka savo vaikams papildomo ugdymo paslaugas (būreliai, ìvairūs papildomi užsièmimai, pomokyklinė veikla ar privatus ugdymas), kurios yra svarbios vaiko tikslingai raidai. Pagal teiginių dažnį matome, kad I grupès tèvai daugiausia perka individualią specialistų pagalbą bei
6 lentelè. Pagalba, paslaugos, kurias perka tèvai, auginantys mokyklinio amžiaus vaiką su ASS

\begin{tabular}{|c|c|c|c|}
\hline Kategorija & Subkategorija & Teiginiai & $\begin{array}{c}\text { Teiginiụ } \\
\text { dažnis }\end{array}$ \\
\hline $\begin{array}{l}\text { Parama spec. } \\
\text { ugdymui }\end{array}$ & $\begin{array}{l}\text { Papildomas } \\
\text { ugdymas }\end{array}$ & $\begin{array}{l}\text { "Visa kita gauname iš privačios } \\
\text { mokyklos", "vaiko vasaros sto- } \\
\text { vyklą", "bureliai", "papildomas } \\
\text { mokslas", "Visas papildomas vei- } \\
\text { klas...", "Vaiko ugdymas...", "... } \\
\text { privati mokykla", "pomokykline } \\
\text { veikla, bureliai", "....buvome sto- } \\
\text { vyklose specialiuose..." } \\
\text { "individualus ugdymas...užklasi- } \\
\text { nės veiklos" }\end{array}$ & 12 \\
\hline \multirow[t]{2}{*}{$\begin{array}{l}\text { Parama reabi- } \\
\text { litacijai }\end{array}$} & $\begin{array}{l}\text { Specialistų } \\
\text { konsultacijos }\end{array}$ & $\begin{array}{l}\text { "Psichologo", "Logopedas", "Spe- } \\
\text { cialistų pagalbą...", " ... spec. pe- } \\
\text { dagogas..." }\end{array}$ & 23 \\
\hline & $\begin{array}{l}\text { Reabilitacija } \\
\text { ligoninèse/ } \\
\text { sanatorijose/ }\end{array}$ & 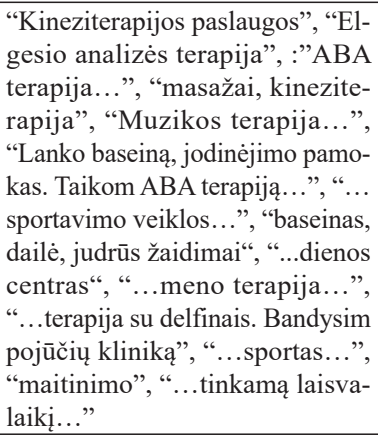 & 26 \\
\hline \multirow[t]{3}{*}{$\begin{array}{l}\text { Kitos paslau- } \\
\text { gos }\end{array}$} & Med.paslaugos & $\begin{array}{l}\text { "Odontologo, psichiatro", "Me- } \\
\text { dicininė pagalba", "netradicinè } \\
\text { medicina", "Vaistai...", }\end{array}$ & 5 \\
\hline & $\begin{array}{l}\text { Priemonès, } \\
\text { žaislai ir kiti } \\
\text { reikalingi daik- } \\
\text { tai }\end{array}$ & $\begin{array}{l}\text { "Ortopedinę avalynę, akinukus”, } \\
\text { "...lavinimo priemones”, "pagal- } \\
\text { binis inventorius...”, }\end{array}$ & 3 \\
\hline & Vaiko priežiūra & $\begin{array}{l}\text { "nuolatinè priežiūra ne mokymo } \\
\text { istaigoje", "“...prižiūrintị asmuo..", } \\
\text { "...auklè namuose...", " ...auklè- } \\
\text { toja...", "Vaiką ne mokykloje kai } \\
\text { tėvų nèra prižiūri auklè-specia- } \\
\text { listas", }\end{array}$ & 6 \\
\hline
\end{tabular}

konsultacijas nei II grupès tèvai.

Anot Siller, tèvai su aukštesniu socioekonominiu statusu yra labiau linkę savo vaiką ugdyti privačiai, papildomai samdyti privačius specialistus, taikančius ịvairaus spektro paslaugas [13]. Pasak Lindley ir Mark, tèvai, auginantys ikimokyklinio amžiaus vaiką, perka daugiau sveikatos priežiūros paslaugų, norèdami kuo greičiau pagerinti vaiko būklę ir patiria didesnę finansinę naštą [14]. Anot mokslininkų, dauguma tėvų skundžiasi, kad jiems trūksta specialistų pagalbos, nes specialistų paslaugos būna arba nepasiekiamos tėvams, arba tiesiog per brangios [10]. Tẻvai nurodo, kad gauna nepakankamai informacijos iš specialistų jiems rūpimais klausimais: apie neigalaus vaiko auginimą ir auklëjimą, apie ịvairias paslaugas, teikiamas šeimos sėkmingam funkcionavimui palaikyti, nes per mažai kreipiamas dėmesys i 
7 lentelè. Pagalbos, paslaugų trūkumas tėvams, auginantiems ikimokyklinio amžiaus vaiką su ASS

\begin{tabular}{|c|c|c|c|}
\hline Kategorija & Subkategorija & Teiginiai & $\begin{array}{l}\text { Teiginių } \\
\text { dažnis }\end{array}$ \\
\hline \multirow[t]{2}{*}{$\begin{array}{l}\text { Finansinè pa- } \\
\text { rama }\end{array}$} & $\begin{array}{l}\text { Nemokamos } \\
\text { paslaugos }\end{array}$ & $\begin{array}{l}\text { "...platesnio spektro nemokamų specialistų } \\
\text { užsiemimų, nuolaidų medicinos paslaugoms", } \\
\text { "Nemokamų paslaugų daugiau...", " "Bent dali- } \\
\text { nio finansavimo ABA terapijai“", “...norètųsi kad } \\
\text { paslaugos....finansuojamos valstybès" }\end{array}$ & \multirow[t]{2}{*}{16} \\
\hline & $\begin{array}{l}\text { Išlaidų kom- } \\
\text { pensavimo }\end{array}$ & "...išlaidų kompensavimo už vaiko ugdymą“, & \\
\hline \multirow[t]{2}{*}{$\begin{array}{l}\text { Parama spec. } \\
\text { ugdymui }\end{array}$} & $\begin{array}{l}\text { Tikslingas } \\
\text { ugdymas }\end{array}$ & $\begin{array}{l}\text { "Nuoseklaus ugdymo, tikslingų švietimo suteik. } \\
\text { paslaugų, patvirtintos ugdymo metodikos", "Bū- } \\
\text { relių..." }\end{array}$ & \multirow[t]{2}{*}{3} \\
\hline & $\begin{array}{l}\text { Spec. ugdymo } \\
\text { centrai }\end{array}$ & "Specializuotų ugdymo ịstaigų...", & \\
\hline \multirow[t]{2}{*}{$\begin{array}{l}\text { Parama reabi- } \\
\text { lita- } \\
\text { cijai }\end{array}$} & $\begin{array}{l}\text { Specialistų } \\
\text { konsultacijos }\end{array}$ & $\begin{array}{l}\text { "Psichologo, ergoterapeuto...", “...logopedo...”, } \\
\text { "... specialistų, kurie konsultuotų ir tikslingai pa- } \\
\text { tartu, kaip elgtis su vaiku...", "Ypatingai trūksta } \\
\text { ergoterapeutų užsiėmimų...", “.... spec. peda- } \\
\text { gogo", “....savo darbą išmanančių specialistų" }\end{array}$ & 16 \\
\hline & $\begin{array}{l}\text { Reabilitacija } \\
\text { ligoninėse/ } \\
\text { sanatorijose/ }\end{array}$ & 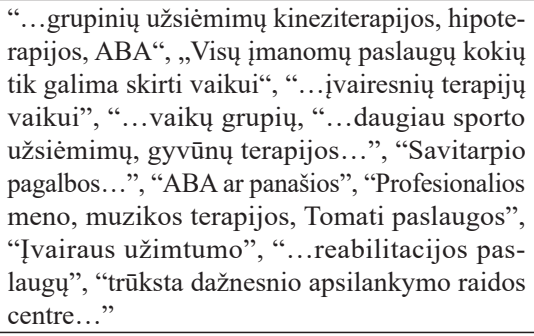 & 23 \\
\hline \multirow[t]{2}{*}{$\begin{array}{l}\text { Kitos paslau- } \\
\text { gos }\end{array}$} & $\begin{array}{l}\text { Psichologo pa- } \\
\text { galba tevams }\end{array}$ & $\begin{array}{l}\text { "Tèvams - psichologinès pagalbos", "...psicho- } \\
\text { logo konsultaciju, kurie dirbtų su šeimos na- } \\
\text { riais", "Patiems (tevvams) pagalbos, paramos...", } \\
\text { "Psichologo pagalbos šeimai..." }\end{array}$ & 5 \\
\hline & $\begin{array}{l}\text { Vaiko prie- } \\
\text { žiūra }\end{array}$ & $\begin{array}{l}\text { "Specializuotų auklès paslaugų - oficialiai...", } \\
\text { "Valstybès apmokomo lydinčio asmens..." }\end{array}$ & 2 \\
\hline
\end{tabular}

šeimos poreikius ir jos vidinius išteklius [12].

Tyrime dalyvavę tèvai nurodè, kad asmeniškai perka medicinines vaiko sveikatos palaikymui paslaugas, ugdymuisi reikalingas ịvairias priemones (lavinančius žaislus ir kitus reikalingus daiktus specialiujjų igūdžių lavinimui), taip pat kitų asmenų pagalbą (vaiko priežiūrą, kada tėvų nėra namie).

Kaip teigia Hodgetts, tèvams, auginantiems 10-24 metu vaiką su raidos sutrikimu, labiausiai reikalinga kito asmens pagalba, vadinama atokvėpio pagalba tėvams [5]. Tẻvai, auginantys vaiką su ASS, patiria daugiau įtampos ir streso, negu tèvai, auginantys vaiką su Dauno sindromu ar su cerebriniu paralyžiumi $[14,1,15,16]$.

Atokvépio pagalba tèvams yra svarbi ir būtina, valstybei rūpinantis šeimos, auginančios vaiką su autizmo spektro sutrikimu, gyvenimo gerove.

Analizuojant trečiojo klausimo duomenis apie šeimos specialiųju paslaugu poreikị, išskirti prasminių tekstų vienetai (subkategorijos) pagal savo tematiką buvo sujungti i keturias kategorijas: finansinè parama, parama specialiajam ugdymui, parama reabilitacijai, kitos paslaugos (7,8 lentelès). Tyrimas nustatè, kad abiejų grupių tėvams trūksta visų rūšių paslaugų (nemokamų, dalinai apmokamų, kompensuojamų paslaugų). Todėl tėvai atiduoda ne tik visą savo laiką vaiko auklèjimui, bet ir poreikių tenkinimui panaudoja didžiają asmeninio šeimos biudžeto dalį. Vienos paslaugos yra nemokamos (apmokamos valstybès), o didžioji dalis jų kainuoja šeimai daug léšų. Tačiau ką daryti šeimoms, kurios gyvena už miesto ribų, kaimuose, miesteliuose, mažose bendruomenėse? Kada yra mažos galimybès pasirinkti specialiąsias paslaugas arba jų visai nèra.

Respondentai ịvardijo specialiojo ugdymosi problemas: nèra tikslingai nukreiptas ị vaiko asmeninius ypatumus; trūksta kokybiškai dirbančių centrų su įvairiomis metodikomis bei programomis, tinkančiomis neigalių vaikų individualiems ugdymosi poreikiams; nepakanka specialistų, dirbančių ugdymosi ịstaigose (darželiuose, mokyklose), nepakankamas demesys neigalių vaikų socializacijai (popamokinè veikla, atostogos, laisvalaikis). Tyrimo duomenimis, tevai pakankamai daug perka reabilitacijos paslaugų asmeniškai, nors jas gauna iš valstybès, tačiau šis poreikis dèl nežinomų priežasčių išlieka didelis.

Tyrimais ịrodyta, kad vaikų su įvairiais raidos sutrikimais tèvai patiria: didžiuli stresą, atskirtị visuomenèje, asmeninès kaltès jausmą, nuovargị ir išsekimą. Mažai dẻmesio skiriama tėvų asmeninei sveikatai [17]. Tévai, kurių streso lygis didesnis, linkę samdyti daugiau specialistų bei ieškoti ìvairių terapijų, paslaugų vaiko gydymui ir ugdymuisi, nei tèvai, kuriems nustatytas mažesnis streso lygis. Ši problema apsunkina šeimos finansinę padètį, kartu nukenčia ir šeimos gerovè [13].

Vertinant šeimų, auginančių neigalius vaikus, gyvenimo gerovę, o perspektyvoje tikètis šioje srityje pozityvių pokyčių, reikia atliekant tyrimus vadovautis sisteminiu požiūriu ir tirti ne tik vidinius ir išorinius šeimos resursus, bet ir valstybès finansinius ekonominius rodiklius, teikiant paramą neigalių vaikų ugdymuisi ir auklejjimui, reabilitacijai ir rekreacijai. Specialistams, teikiantiems paslaugas, svarbu suprasti, ịvertinti bei atsižvelgti ị neigalių vaikų ir šeimos psichosocialinius poreikius. 


\section{Išvados}

1. Ištyrus šeimos gyvenimo gerovès probleminius veiksnius nustatyta, kad šeimos narių tarpusavio sąveika nepriklauso nuo teikiamos paramos neigaliam vaikui, o priklauso nuo emocinès gerovès ir neiggalaus vaiko amžiaus tarpsnio. Emocinè gerovè šeimoje yra susijusi su neigalaus vaiko dèmesingu ir atsakingu auklejjimu, o materiali gerovè sietina su didesne parama ir pagalba, teikiama neigaliam vaikui.

2. Anot respondentu, vaiko negalia poveikio šeimos gerovei neturi, tačiau tyrimas atskleide, kad šeimos vidiniai ir išoriniai resursai daro poveiki gyvenimo kokybès sritims: geri ir glaudūs santykiai šeimoje yra svarbūs neigalių vaikų dèmesingam ir atsakingam auklejjimui, šeimos emocinei gerovei; stiprūs socialiniai santykiai turi glaudžius ryšius su šeimos materialia ir emocine gerove bei siejami su teikiama pagalba neigaliam vaikui.

3. Pagalba ir paslaugos valstybės teikiamos neigaliam vaikui - tèvų netenkina. Dali jų tėvai perka patys, o kitų pageidaujamų ir reikalingų neigalaus vaiko ugdymuisi ir reabilitacijai - tèvai neịperka dèl prastos finansinès padèties.

4. Norint suteiki efektyvią pagalbą šeimoms, auginančioms neịgalų vaiką, svarbu sistemiškai atskleisti jos psichosocialinio funkcionavimo ypatumus bei nustatyti tèvų pagalbos poreikius ir lūkesčius iš formaliu ir (arba) neformalių struktūrų.

\section{Literatūra}

1. Johnson N, Frenn M, Feetham S, Simpson P. Autism spectrum disorder: parenting stress, family functioning and health- related quality of life. Fam Syst Health 2011; 29: 232-52.

2. Predescu E., Sipos R. Cognitive coping strategies, emotional distress and quality of life in mothers of children with ASD and ADHD - A comparative study in a Romanian population sample. Open Journal of Psychiatry 2013; 3:11-17.

3. Bolivar C., Vieira M., Dreux F., Fernandes M. Quality of life of siblings of children included in the autism spectrum. Sociedade Brasileira de Fonoaudiologia 2013; 25(2): $120-127$.
8 lentelė. Pagalbos, paslaugų trūkumas tėvams, auginantiems mokyklinio amžiaus vaiką su ASS

\begin{tabular}{|c|c|c|c|}
\hline Kategorija & Subkategorija & Teiginiai & $\begin{array}{l}\text { Teiginiu } \\
\text { dažnis }\end{array}$ \\
\hline \multirow[t]{2}{*}{$\begin{array}{l}\text { Finansinè } \\
\text { parama }\end{array}$} & $\begin{array}{l}\text { Nemokamos } \\
\text { paslaugos }\end{array}$ & $\begin{array}{l}\text { “...nem. transporto paslaugų...", "Nemokamų } \\
\text { ar kompensuojamų paslaugu“", "Finansinès para- } \\
\text { mos...", }\end{array}$ & \multirow[t]{2}{*}{10} \\
\hline & $\begin{array}{l}\text { Išlaidų kom- } \\
\text { pensavimo }\end{array}$ & $\begin{array}{l}\text { "Bent iš dalies kompensuojamosios ABA (Elge- } \\
\text { sio terapija)", "finansiškai kompensuojamos tos } \\
\text { paslaugos, kurias, perkame" }\end{array}$ & \\
\hline \multirow[t]{2}{*}{$\begin{array}{l}\text { Parama } \\
\text { spec. ugdy- } \\
\text { mui }\end{array}$} & $\begin{array}{l}\text { Tikslingas } \\
\text { ugdymas }\end{array}$ & $\begin{array}{l}\text { "Daugiau pagalbos mokykloje“,"Būrelių...", } \\
\text { "kompiuterinio ugdymo vaikui, anglų k.", “...in- } \\
\text { dividualus ugdymas", " Vaikų su spec. poreikiais } \\
\text { inkliuzijos ị vidurines mokyklas", "daugiau pomo- } \\
\text { kyklinès veiklos", }\end{array}$ & 8 \\
\hline & $\begin{array}{l}\text { Spec. ugdymo } \\
\text { centrai }\end{array}$ & $\begin{array}{l}\text { „Daugiau įstaigu - centrų, teikiančių įvairialypio } \\
\text { spektro paslaugų", “....centrų, kur vaikas, sulaukęs } \\
\text { pilnametystess, atrastų savo nišą gyvenime“, “... } \\
\text { centrų, kur mūsų vaikai praleistų vasaros atosto- } \\
\text { gas", "Mokymo ịstaigų, kur vaikas būtų tinkamai } \\
\text { integruotas“" }\end{array}$ & 5 \\
\hline \multirow[t]{2}{*}{$\begin{array}{l}\text { Parama } \\
\text { reabilita- } \\
\text { cijai }\end{array}$} & $\begin{array}{l}\text { Specialistų } \\
\text { konsultacijos }\end{array}$ & $\begin{array}{l}\text { "Psichologo, pedagogo paslaugų, logopedo, spec. } \\
\text { pedagogo", “...ABA terapeuto", "trūksta ergote- } \\
\text { rapeutų, kineziterapeutų, muzikos terapeutų..." }\end{array}$ & 11 \\
\hline & $\begin{array}{l}\text { Reabilitacija } \\
\text { ligoninėse/ } \\
\text { sanatorijose/ }\end{array}$ & 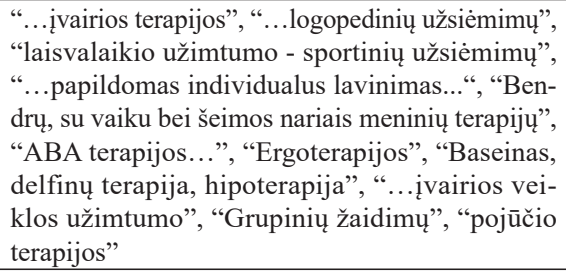 & 23 \\
\hline \multirow[t]{2}{*}{$\begin{array}{l}\text { Kitos } \\
\text { paslaugos }\end{array}$} & $\begin{array}{l}\text { Psichologo pa- } \\
\text { galba tèvams }\end{array}$ & $\begin{array}{l}\text { "...psichologo pagalbos šeimai", "Psichologo pa- } \\
\text { galbos skirtos suaugusiems" }\end{array}$ & 3 \\
\hline & $\begin{array}{l}\text { Vaiko prie- } \\
\text { žiūra }\end{array}$ & $\begin{array}{l}\text { "nuolatinès priežiūros ne mokslo ịstaigoje”, “... } \\
\text { prižiūrintị asmuo...", “ Trūksta prižiūrinčių vaikus } \\
\text { specialistų ne darbo dienomis“" }\end{array}$ & 4 \\
\hline
\end{tabular}

4. Zablotsky B, Kalb GL, Freedman B, Vasa R ir kt. Health care experiences and perceived financial impact among families of children with an autism spectrum disorder. Psychiatr Serv 2014; 65(3):395-398.

5. Hodgetts S, Zwaigenbaum L, Nicholas D. Profile and predictors of service needs for families of children with autism spectrum disorders. Autism 2015; 9(6):673-683.

6. Thomas KC, Parish SL, Rose RA. et al. (2012) Access to care for children with autism in the context of state Medicaid reimbursement. Maternal and Child Health Journal 2012; 16:1636-1644.

7. Hong Y.J., Turnbull A. Family quality of life from the perspectives of individual family members: a Korean-American family and deafness. International Journal of Special Education 2013; 28(2):1-14.

8. Hu.X, Summers AJ, Turnbull A, Zuna N. The quantitative measurement of family quality of: a review of available instruments. Journal of Intellectual Disability Reaserch 2011; 55(12):1098-1114.

9. Žydžiūnaitė V., Sabaliauskas S. Kokybiniai tyrimai, principai ir metodai. Vadovèlis, Vaga, 2017.

10. Mackintosh HV, Goin-Kochel PR, Myers JB. What do you like/dislike about the treatments you're currently using?" A qualitative study of parents of children with 
8 lentelès tęsinys

\begin{tabular}{|c|c|c|c|}
\hline Kategorija & Subkategorija & Teiginiai & $\begin{array}{c}\text { Teiginiù } \\
\text { dažnis }\end{array}$ \\
\hline \multirow[t]{2}{*}{$\begin{array}{l}\text { Finansinè } \\
\text { parama }\end{array}$} & $\begin{array}{l}\text { Nemokamos } \\
\text { paslaugos }\end{array}$ & $\begin{array}{l}\text { "...nem. transporto paslaugų...", "Nemokamų } \\
\text { ar kompensuojamų paslaugų", "Finansinès pa- } \\
\text { ramos...", }\end{array}$ & \multirow[t]{2}{*}{10} \\
\hline & $\begin{array}{l}\text { Išlaidų kom- } \\
\text { pensavimo }\end{array}$ & $\begin{array}{l}\text { "Bent iš dalies kompensuojamosios ABA (Elge- } \\
\text { sio terapija)", "finansiškai kompensuojamos tos } \\
\text { paslaugos, kurias, perkame" }\end{array}$ & \\
\hline \multirow[t]{2}{*}{$\begin{array}{l}\text { Parama } \\
\text { spec. ugdy- } \\
\text { mui }\end{array}$} & $\begin{array}{l}\text { Tikslingas ug- } \\
\text { dymas }\end{array}$ & $\begin{array}{l}\text { "Daugiau pagalbos mokykloje“,"Būrelių...", } \\
\text { "kompiuterinio ugdymo vaikui, anglų k.“, “... } \\
\text { individualus ugdymas", " Vaikų su spec. porei- } \\
\text { kiais inkliuzijos ị vidurines mokyklas", "daugiau } \\
\text { pomokyklinès veiklos", }\end{array}$ & 8 \\
\hline & $\begin{array}{l}\text { Spec. ugdymo } \\
\text { centrai }\end{array}$ & $\begin{array}{l}\text { „Daugiau ịstaigų - centrų, teikiančių ịvairialypio } \\
\text { spektro paslaugų“, “....centrų, kur vaiką sulaukus } \\
\text { pilnametystės atrastų savo nišą gyvenime“, “... } \\
\text { centrų, kur mūsų vaikai praleistų vasaros atosto- } \\
\text { gas", "Mokymo įstaigų, kur vaikas būtų tinkamai } \\
\text { integruotas“, }\end{array}$ & 5 \\
\hline \multirow[t]{2}{*}{$\begin{array}{l}\text { Parama } \\
\text { reabilita- } \\
\text { cijai }\end{array}$} & $\begin{array}{l}\text { Specialistu } \\
\text { konsultacijos }\end{array}$ & $\begin{array}{l}\text { "Psichologo, pedagogo paslaugų, logopedo, spec. } \\
\text { pedagogo", "...ABA terapeuto", "trūksta ergote- } \\
\text { rapeutų, kineziterapeutu, muzikos terapeutų..." }\end{array}$ & 11 \\
\hline & $\begin{array}{l}\text { Reabilitacija } \\
\text { ligoninėse/ } \\
\text { sanatorijose/ }\end{array}$ & 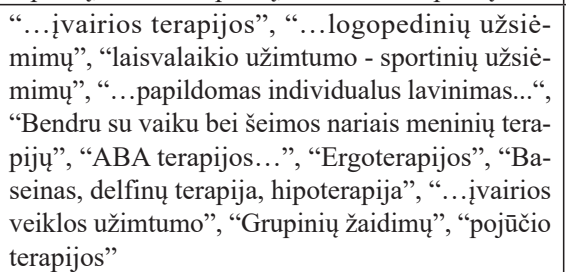 & 23 \\
\hline \multirow[t]{2}{*}{$\begin{array}{l}\text { Kitos pa- } \\
\text { slaugos }\end{array}$} & $\begin{array}{l}\text { Psichologo pa- } \\
\text { galba tėvams }\end{array}$ & $\begin{array}{l}\text { "...psichologo pagalbos šeimai", "Psichologo } \\
\text { pagalbos skirtos suaugusiems" }\end{array}$ & 3 \\
\hline & Vaiko priežiūra & $\begin{array}{l}\text { "nuolatinės priežiūros ne mokslo ịstaigoje”, “... } \\
\text { prižiūrintį asmuo...", " Trūksta prižiūrinčių vaikus } \\
\text { specialistų ne darbo dienomis“" }\end{array}$ & 4 \\
\hline
\end{tabular}

autism spectrum disorders. Focus on autism and other developmental disabilities, 2012; 27(1):51 -60.

11. Raudeliūnaitè R. Šeimų, auginančių vaikus su negalia, psichosocialinė situacija. Societal Innovations for Global Growth 2012; 1(1):849-864.

12. Siller M, Reyes N, Hotez E ir kt. Longitudinal change in the use of services in autism spectrum disorder: Understanding the role of child characteristics, family demographics, and parent cognitions. Autism 2014; 18(4):433-446.

13. Lindley CL, Mark AB. Children with special health care needs: Impact of health care expenditures on family financial burden. Journal of Child and Family Studies 2010; 19(1):79-89.

14. Eapen V, Crncec R, Walter A ir Tay KP. Conceptualisation and development of a quality of life measure for parents of children with autism spectrum disorder. Autism Research and Treatment 2014; 1:1-11.

15. Czenczek E, Szeliga E, Przygoda L. Quality of life among parents of children with autism. Rosznik 2012; 10(4):446-454.

16. Dardas AL, Ahmad MM. Coping strategies as mediators and moderators between stress and quality of life among parents of children with autistic disorder. Stress Health 2015; 31(1):5-12.

17. Malhotra Sh, Khan W, Bhatia MS. Quality of life of parents having children with developmental disabilities. Delhi Psychiatry Journal 2012; 15(1):171-176.

\section{QUALITY OF LIFE OF FAMILIES,RAISING CHILDREN WITH AUTISM SPECTRUM DISORDER}

\section{Samsonienė, M. B. Malkin, J. Kairys,}

\section{A. Juozulynas}

Key words: parents, children with autism spectrum disorder, quality of life, special needs.

Summary

The aim of this study is to reveal problematic factors of family quality of life between parents raising preschool and school-age children with autism spectrum disorder. The study involved 100 parents of preschool and school age children with autism spectrum disorder. Coherent research strategy was applied, using the questionnaire with closed and open-ended questions. The questionnaire of closed-ended questions was designed to explore the family quality of life of families raising a child with autism spectrum disorder, and open-ended questions - to address features of meeting special needs of family. The research data was analyzed using Microsoft Excel and SPSS programs. Results. For the reciprocity of family members of families raising preschoolage disabled child are important such factors as nurturing of disabled child $(\mathrm{r}=0,66)$, material $(\mathrm{r}=0,53)$ and emotional $(\mathrm{r}=0,51)$ family welfare, while for parents, raising school-age disabled child nurturing $(\mathrm{r}=0,53)$ and material welfare $(\mathrm{r}=0,53)$. Respondents rated poorly support from the state for the special needs of the family. Only part of the services, necessary for the development of their disabled child, they could afford themselves, while other part of the services they could not afford due to the poor financial situation of the family.

Conclusions. Public efforts to take care of living prosperity of families with a disabled child depends on ability to systematically reveal the peculiarities of psychosocial functioning of relationships in the family and social relationships as well as on the needs and expectations of professional assistance to the family from formal and/ or informal structures.

Correspondence to: airidas@vdnet.lt

Gauta 2017-06-13 